\title{
Simulium Iobatoi, New Species of Blackfly (Diptera: Simuliidae) from the States of Mato Grosso and Goiás, Central Brazil
}

\author{
APA Luna Dias, LM Hernández*/+, M Maia-Herzog, AJ Shelley* \\ Departamento de Entomologia, Instituto Oswaldo Cruz-Fiocruz, Rio de Janeiro, RJ, Brasil *Simuliidae and Onchocerciasis \\ Research Programme, Biomedical Sciences Theme, Department of Entomology, The Natural History Museum, Cromwell Road, \\ SW7 5BD, London, UK \\ During studies on the taxonomy of the Simuliidae of Brazil, a new species of Simulium was found. Full descrip- \\ tions of the adults and pupae of this species are described here, its affinities with other species are discussed and its \\ distribution, biology, and medical importance in Brazil are recorded.
}

Key words: Simuliidae - Neotropical region - taxonomy - Simulium lobatoi - onchocerciasis - Mato Grosso - Goiás - Brazil

The discovery of several onchocerciasis foci in Central and South America has greatly contributed to our present knowledge of the systematics of Simuliidae in the Neotropical Region. In Brazil, the disease was first discovered 30 years ago in the states of Roraima and Amazonas (Shelley 1988) and, more recently, in Minaçu, state of Goiás (Maia-Herzog et al. 1999). Several revisionary studies on the epidemiology and dispersal of this disease have been published in the last decade (Py-Daniel 1997, Shelley et al. 1997, 2001a, Shelley 2002) together with the description of several new species and species complexes, as collecting efforts and taxonomic research continue on this morphologically homogeneous group (e.g. Coscarón et al. 1992, Charalambous et al. 1996, Hamada \& Adler 1998a, b, 1999, Hamada 2000, Strieder \& Coscarón 2000, Strieder \& Py-Daniel 2000, Shelley et al. 2001b, Hamada et al. 2003). Further collecting of simuliids in the states of Mato Grosso and Goiás has revealed the presence of a new species, which is described in this paper.

\section{MATERIALS AND METHODS}

The techniques for collection, dissection, and measurements of specimens as well as the terminology used in the species description are those detailed in Shelley et al. (1997, 2000, 2002). Images illustrating the morphology were obtained directly from the specimens using a Synoptics composite image analysis system (Shelley et al. 2000) and have been stored on CDs in The Natural History Museum, London (BMNH). Type specimens have been deposited in the Entomology Departments of the BMNH and the Oswaldo Cruz Institute (IOC), as indicated in material examined.

Logistical support: Furnas Centrais Elétricas, CNPq, and Funasa ${ }^{+}$Corresponding author. Fax: +44-0207-942.5661. E-mail: luih@nhm.ac.uk

Received 2 September 2003

Accepted 16 December 2003

\section{DESCRIPTION}

Simulium lobatoi, new species

Luna Dias, Hernández, Maia-Herzog \& Shelley

(Figs 1-25)

FEMALE. General body colour dark brown. Body length (specimens pinned) $2.6-3.6 \mathrm{~mm}(\overline{\mathrm{X}}=3.1 \mathrm{~mm}$, s.d. $=0.28, \mathrm{n}$ $=14)$, wing length $2.4-2.9 \mathrm{~mm}(\overline{\mathrm{X}}=2.7 \mathrm{~mm}$, s.d. $=0.16, \mathrm{n}=$ 14), wing width $1.0-1.4 \mathrm{~mm}(\overline{\mathrm{X}}=1.2 \mathrm{~mm}, \mathrm{~s} . \mathrm{d} .=0.14, \mathrm{n}=14)$. Head - Dichoptic with dark red eyes and nudiocular area well developed (Fig. 1). Frons, clypeus, and occiput black, with silvery grey pruinosity; clypeus and frons covered with semi-recumbent brown hairs. Mouthparts and maxillary palps dark brown. Antennae with scape and pedicel yellowish brown, rest of flagellum dark brown. Cibarium with well developed, sclerotised cornuae and without teeth (Fig. 2).

Thorax - Scutum dark brown with evenly arranged, recumbent, whitish setae, interspersed with fine, semi-recumbent brown setae; posterior margin with long dark hairs. Scutal pattern varying slightly with illumination. With anterior illumination, thorax dark brown with $1+1$ submedian, white vittae, beginning near anterior border of scutum and curving towards mid line in anterior fourth of scutum from where they diverge to lateral margins, terminating at a point two thirds of length of scutum; 1 median, fine, vitta beginning on anterior margin and running in a straight line for two thirds length of scutum; area between vittae and lateral margins dark brown, humeri brown with silver pruinose reflections (Fig. 3). With posterior illumination, thorax dark brown, with $1+1$ longitudinal, wide, silver pruinose, median vittae divided by median dark brown line, $1+1$ rounded, sub-median, pruinose areas near anterior margin, and lateral margins silver pruinose in anterior half of scutum (Fig. 4). Scutellum dark brown with recumbent white hairs intermixed with long, brown bristles. Postnotum dark brown with silver pruinosity. Pleura brown with silver pruinosity. Costa of wing with dense distribution of spines and setae. Subcosta with line of setae along its length. Radius with numerous setae intermixed with distinct spines, basal section of radius bare (Fig. 5). Basal tuft of long, dark setae. Leg coloration and proportions as in Fig. 6. Coxae, femora, trochanters and tibiae of fore and mid legs brown, apex of femora and tibiae darker brown; 
fore tarsal segments and apex of tarsal segments I, II, and III of mid leg dark brown to black, base of tarsal segments I, II, and III of mid legs whitish; basal articulation of mid tibiae yellowish. Hind leg with coxa, femur and tibia brown, trochanter, and basal articulation of femur yellow; half of tarsal segment I and base of segment II whitish, remaining of segments dark brown. Halteres cream yellow with brown base.
Abdomen - Tergites I-IX dark brown to black and brown mottled in middle without silver pruinosity, except tergite II silver pruinose on posterior and lateral margins (Fig. 8). Tergal plates well developed in pinned specimens examined. Sternites and genitalia dark brown to black. Eighth sternite sclerotised with long, irregularly distributed setae on posterior margin; gonopophyses nearly as long as length of eighth sternite at mid point, sub-triangular,

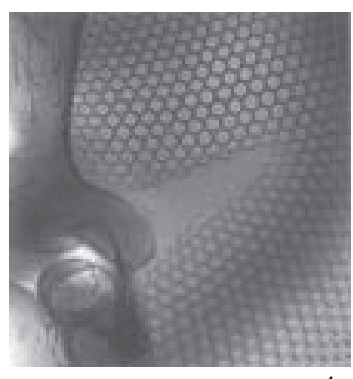

1

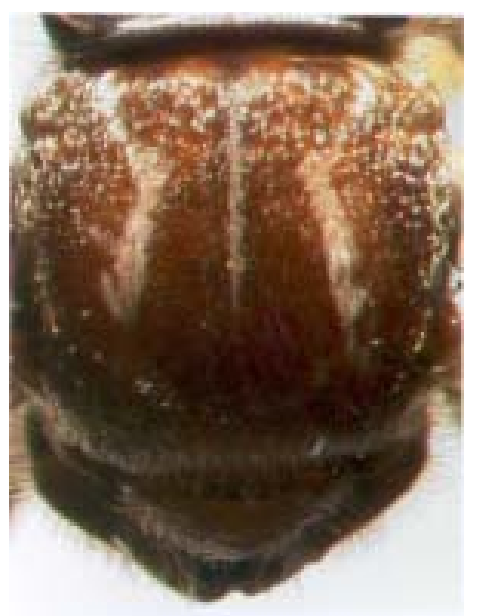

3
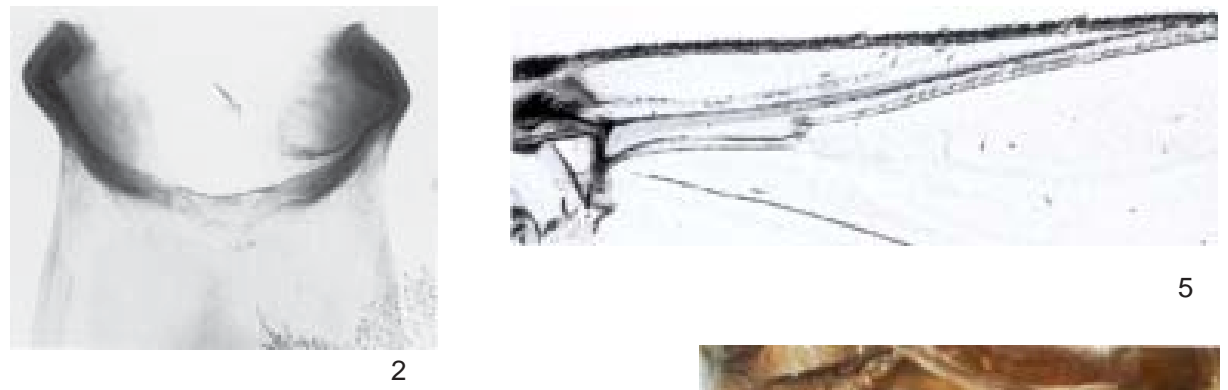

5

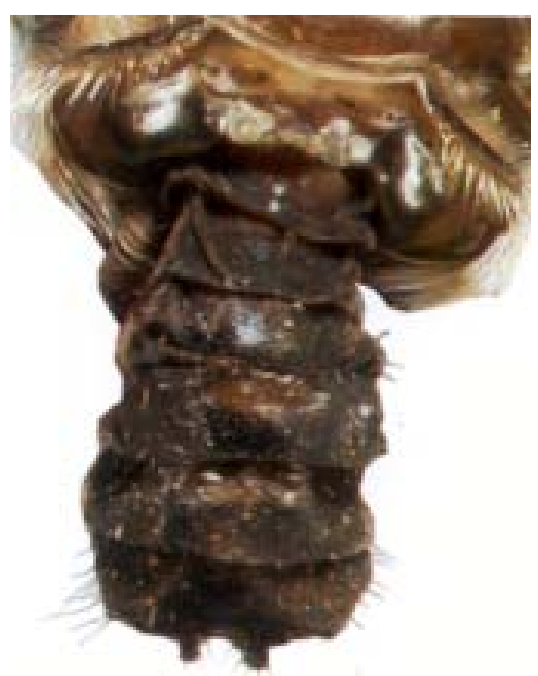

8

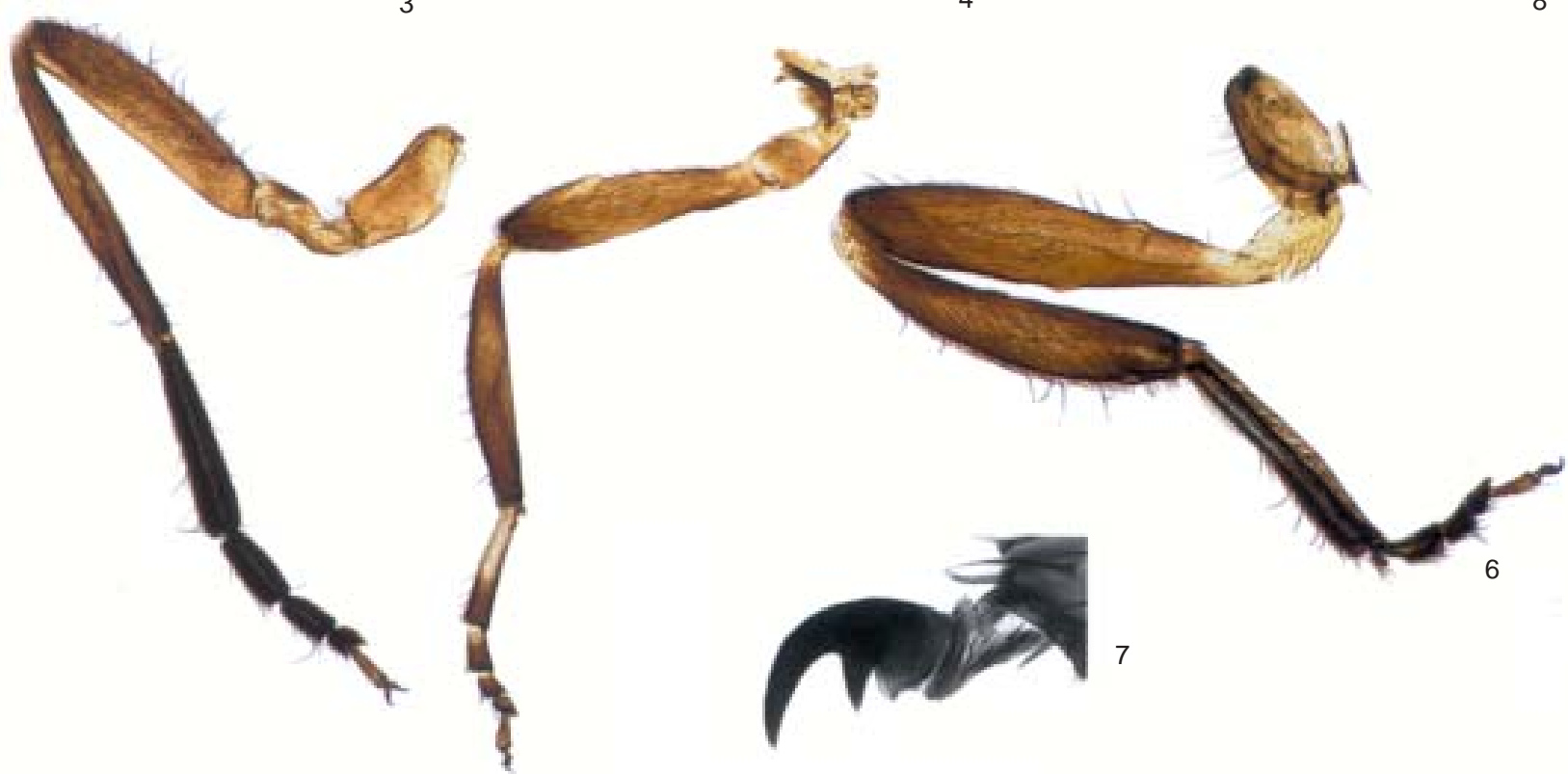

Simulium lobatoi female. Fig. 1: nudiocular area. Fig. 2: cibarium. Fig. 3: scutal pattern (light source anterior). Fig. 4: scutal pattern (light source posterior). Fig. 5: anterior wing veins. Fig. 6: fore, mid, and hind legs. Fig. 7: claw of hind leg. Fig. 8: abdomen 
weakly sclerotised, rounded apically with long setae distributed over entire surface (Fig. 9). Cerci hemispherical, covered with brown setae; paraproct sub-quadrangular, same length as cercus, weakly sclerotised on external margin and membranous apically; paraproct covered with prominent brown setae (Fig. 10). Genital fork stout and sclerotised; termination of lateral arms with anterior margin curved and well developed; anterior processes well developed and blunt apically, posterior processes weakly developed (Fig. 11). Spermatheca globular, with weak external sculpturing and small groups of spicules on inter- nal surface; area of insertion of spermathecal duct weakly sclerotised.

MALE. General body colour dark brown to black. Body length (specimens pinned) $2.7-3.6 \mathrm{~mm}(\overline{\mathrm{X}}=3.2 \mathrm{~mm}$, s.d. $=$ $0.32, \mathrm{n}=10)$, wing length $2.0-2.7 \mathrm{~mm}(\overline{\mathrm{X}}=2.4 \mathrm{~mm}$, s.d.= $0.21, \mathrm{n}=10)$, wing width $1.1-1.3 \mathrm{~mm}(\overline{\mathrm{X}}=1.2 \mathrm{~mm}$; s.d. $=0.21$, $\mathrm{n}=10)$.

Head - Holoptic with dark red eyes. Rest of head coloration as in female.

Thorax - Scutum dark in posterior two thirds and orange in anterior one third with evenly distributed yellowish
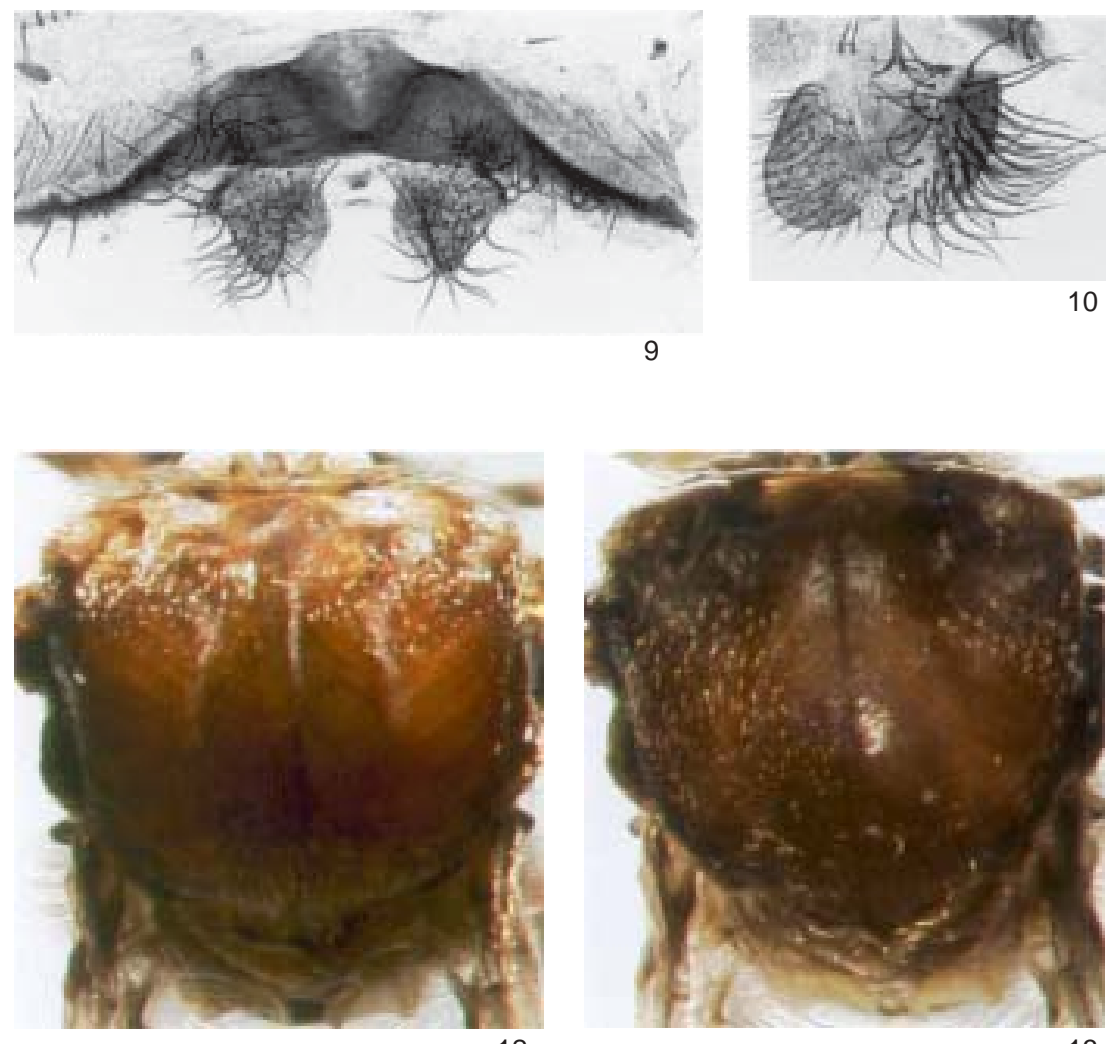

12
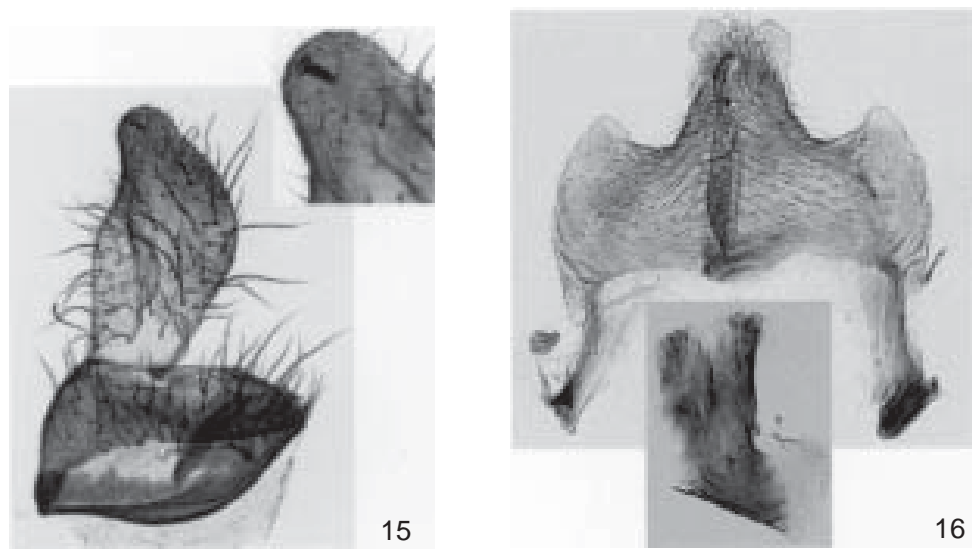

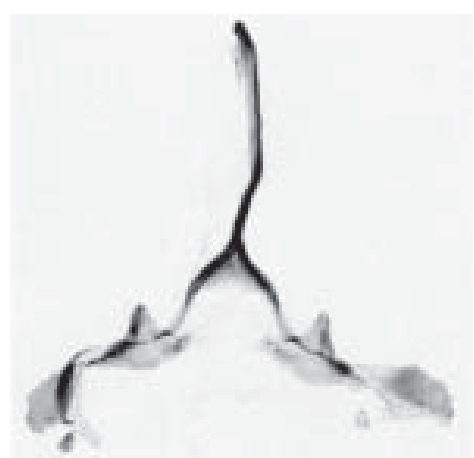

11
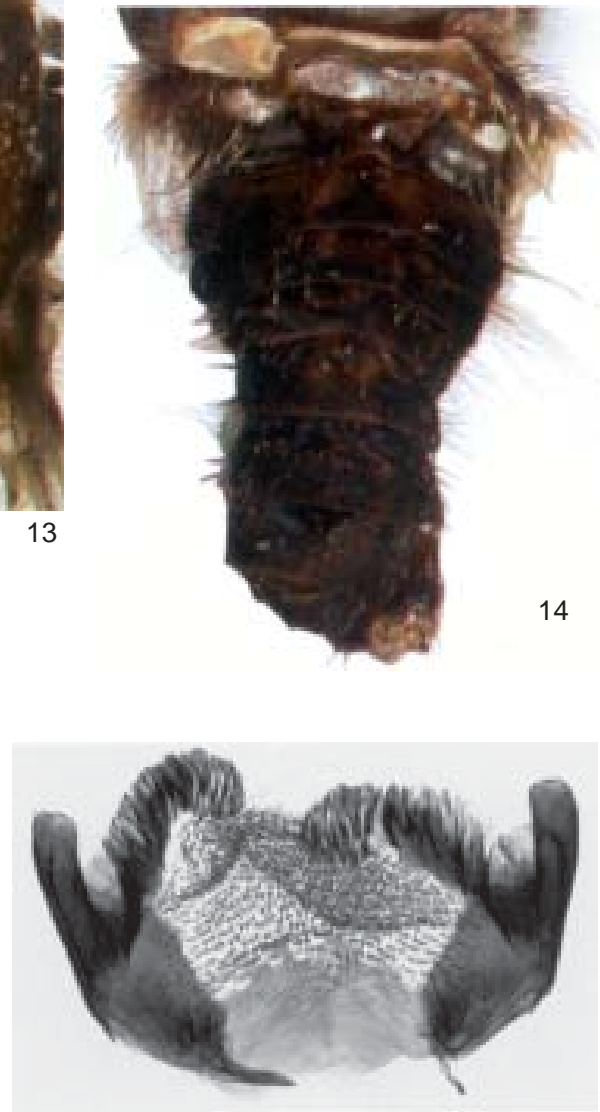

17

Simulium lobatoi female and male. Female - Fig. 9: eight sternite and gonopophyses. Fig. 10: cercus and paraproct. Fig. 11: genital fork. Male - Fig. 12: scutal pattern (light source anterior). Fig. 13: scutal pattern (light source posterior). Fig. 14: abdomen. Fig. 15: gonocoxite and gonostyle; inset, detail of apical spine. Fig. 16: ventral plate and median sclerite. Fig. 17: paramere 
hairs interspersed with recumbent and semi-erect brown hairs. Scutal pattern varies slightly with light incidence: with light source anterior thorax dark brown, with single median and $1+1$ sub-median, white vittae, beginning near anterior border of scutum and diverging to lateral margins; vittae running nearly to mid point of thorax (Fig. 12). With posterior illumination, thorax dark brown, with $1+1$ median, pruinose, pear-shaped vittae near anterior margin divided by median brown line running from anterior to posterior margins (pruinose areas can be observed on antero-lateral margins with some lights); posterior margin dark brown to black (Fig. 13). Humeri and lateral margins dark brown with pruinose area. Scutellum brown with golden, recumbent hairs and long, erect, dark brown setae. Postnotum brown with silvery grey pruinosity. Wing setation as in female, except Subcosta bare in two specimens examined. Leg coloration as in female.

Abdomen - Tergites dark brown to black, basal fringe with long, brown hairs. Pruinose ornamentation on antero-lateral margins of tergite II and lateral margins of tergites III to VIII (best seen in some specimens when tilted and viewed laterally) (Fig. 14). Genitalia brown; sternal plates developed. Gonocoxite sub-quadrangular; gonostyle subrectangular with dorsal and ventral margins sinuous, terminating in single, stout spine; gonocoxite and gonostyle covered with long setae (Fig. 15). Ventral plate weakly sclerotised, sub-rectangular, covered with long hair; keel well developed, with distinct depression apically; basal arms well developed and sub-parallel (Fig. 16). Median sclerite long, about three times longer than wide at widest point, with small incision (appears curled up in all specimens examined) and small spines at apex (Fig. 16). Paramere with well developed and sclerotised basal process and numerous long spines along whole length (Fig. 17).

PUPA. Cocoon length dorsally $2.5-3.6 \mathrm{~mm}(\overline{\mathrm{X}}=3.1 \mathrm{~mm}$, s.d $=0.28, \mathrm{n}=27)$, ventrally $3.9-6.0 \mathrm{~mm}(\overline{\mathrm{X}}=5.0 \mathrm{~mm}$, s.d. $=0.53$, $\mathrm{n}=26)$; pupa length $3.6-5.1 \mathrm{~mm}(\overline{\mathrm{X}}=4.3 \mathrm{~mm}$, s.d. $=0.44, \mathrm{n}$ $=14)$; gill length $0.9-1.8 \mathrm{~mm}(\overline{\mathrm{X}}=1.3$, s.d. $=0.18, \mathrm{n}=32)$.

Cocoon shoe-shaped, brown to black, composed of thick, coalesced fibres with reinforced rim to anterior aperture, margin of aperture weakly to strongly elevated (Figs 18-19).

Gill light brown with eight upwardly-directed filaments arranged in bunch in vertical plane (Fig. 20). Gill configuration with filaments branching basally at different heights (Fig. 21); main trunk short, giving rise to two sets of primary branches, one internal and two external: the more external consists of one dorsal branch with four secondary branches that bifurcate at different heights and one single ventral; the internal branch consists of three secondary branches that bifurcate at different heights. Gill filament variation was only found in one specimen, in which the filaments of the dorsal branch of the external set were much smaller than those of the internal one (Figs 22-23). Filaments stout, pointed distally, without spicules on surface, edges weakly crenate; all filaments approximately same length, except ventral filament which is longer.

Head with $2+2$ frontal and $1+1$ facial small, simple trichomes, and 1+1 small, sub-lateral, simple trichomes between frontal and facial trichomes (Fig. 24). Frontoclypeus with group of platelets mesally, $1+1$ groups dorso-laterally and 2-3 platelets in groups of two or three laterally in frontal region, respectively; tubercles absent in frontal region, but rounded and well distributed over entire surface in facial region (Fig. 25).

Thorax with 1-4 simple trichomes near margin of dorsal cleft and 1-4 simple trichomes on alar region; tubercles mostly rounded only visible at base of gill and posterolateral margin of dorsal cleft.

Abdominal tergite I with $1+1$ simple, short setae laterally and rounded tubercles densely distributed on anterior margin, and entire area of posterior margin; tergite II with $3+3$ sub-median spines in longitudinal row, $3+3$ simple, short setae lateral to outermost spine and rounded tubercles densely distributed mesally; tergites III and IV with $4+4$ sub-median simple hooks in longitudinal row, $1+1$ simple, short setae anterior to most lateral of the hooks; tergites V-VII without setae; tergite IX without terminal spines, weakly sclerotised. Spine comb distribution as follows: $1+1$ groups on antero-lateral margin and 1 group on central portion of anterior margin of tergites IIIVII. Sternite IV with $2+2$ simple, small setae sub-laterally; sternite $\mathrm{V}$ with two sub-lateral, simple setae, $1+1$ close, simple hooks laterally and spine combs on anterior margin; sternite VI with $2+2$ separated, simple, median hooks, $1+1$ simple setae on posterior margin, and group of spine combs on anterior margin; sternites VII with $2+2$ well separated hooks, and groups of spine combs on antero-lateral margin; sternite IX with spine combs on anterior margin.

\section{LARVA. Unknown.}

\section{TAXONOMIC DISCUSSION}

The subgeneric classification of the Neotropical Simuliidae is currently unstable and will shortly be revised by two different research groups. We have therefore not attempted to place S. lobatoi in a subgenus. According to the taxonomic and geographical inventory of World Blackflies (Crosskey \& Howard 1997) it is related to species in the subgenera Hemicnetha Enderlein and Trichodagmia Enderlein.

By comparison largely with species in image archives in the BMNH and IOC collections, and published illustrations of species known to be present in Brazil S. lobatoi is morphologically similar to several species. It is most similar in coloration to $S$. virgatum s.l. Coquillett and its close relatives S. paynei Vargas from Ecuador and S. rubrithorax Lutz from Brazil, as well as to $S$. brachycladum Lutz and Pinto from Brazil (see Maia-Herzog et al. 1984, Shelley et al. 1989, 1997, 2002 for descriptions and taxonomic discussions). The last four species have a female scutal pattern of the same basic design consisting of $1+1$ sub-median bowed vittae that converge posteriorly [BMNH image archives and Figs 45-56 in Shelley et al. (2002) for colour images], while S. lobatoi (Figs 3, 4) has the sub-median vittae diverging posteriorly. In addition to coloration female $S$. lobatoi is distinguished from $S$. virgatum s.l. and its two relatives and S. brachycladum by its short, sub-triangular highly setose gonopophyses (Fig. 9), which are elongated with fine setae in the latter four. S. lobatoi is distinctive in its small, sub-quadrangu- 
lar paraprocts, which are covered only with prominent setae compared to the other species that have well developed paraprocts covered with fine setae (Fig. 10).

The male scutal pattern is different to those of brown- coloured S. virgatum s.l. and its relatives S. paynei, and $S$. rubrithorax in that the posteriorly diverging sub-median vittae in these species are reduced to sub-median anterior cunae in S. lobatoi. In this respect, it is similar to
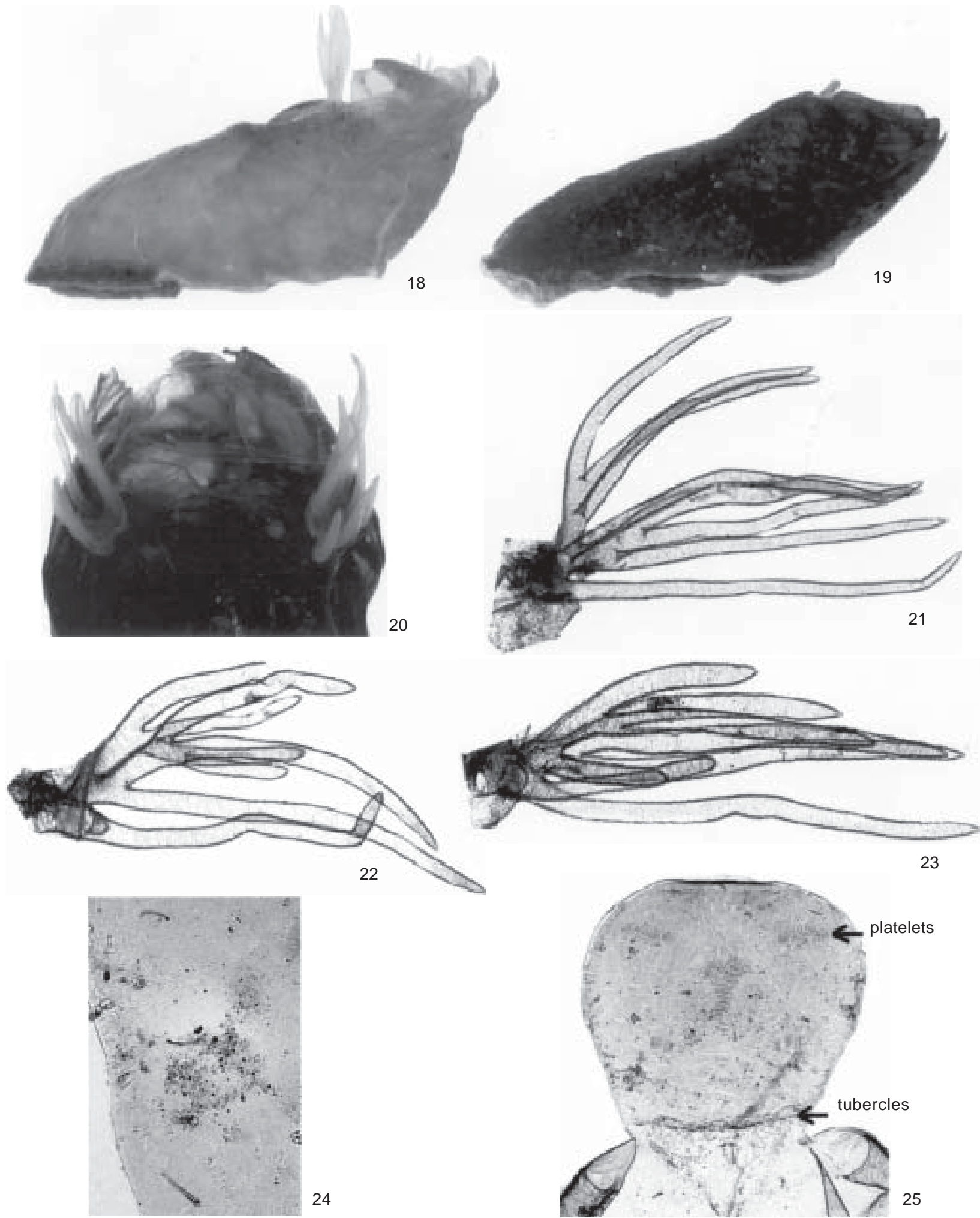

24

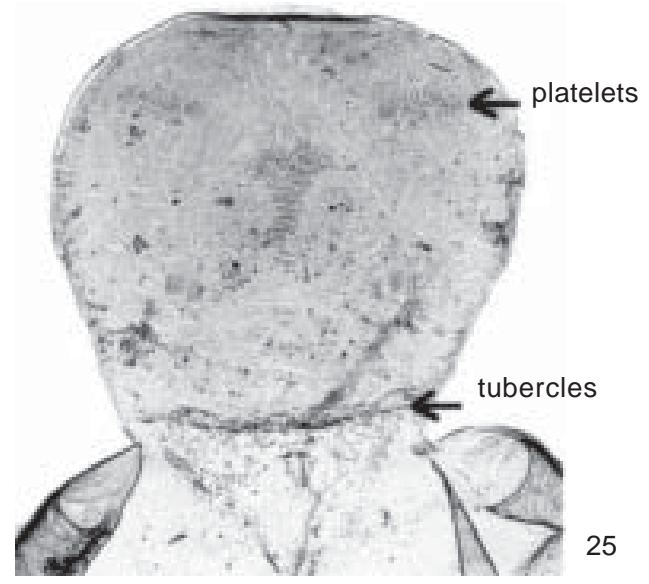

Simulium lobatoi pupa. Fig. 18: cocoon (margin of aperture weakly elevated). Fig: 19: cocoon (margin of aperture strongly elevated). Fig. 20: gill in view of cocoon and pupa. Fig. 21: gill configuration (typical form). Figs 22-23: gill variation in specimen from Cachoeira de Lageado. Fig. 22: left gill. Fig. 23: right gill. Fig. 24: frontal trichomes of frontoclypeus. Fig. 25: frontoclypeus 
S. brachycladum and S. cristalinum Coscarón \& PyDaniel, except that the latter species is dark brown to black and has a broader median vitta with an anterior light source. Males of S. lobatoi are distinguished by the less developed keel showing a distinct depression apically, which is lacking in the elongated keels of S. paynei, S. rubrithorax, S. virgatum s.l., S. brachycladum, and S. cristalinum.

S. lobatoi, S. paynei, S. rubrithorax, and S. virgatum s.l. have eight gill filaments, which immediately separate them from S. brachycladum and S. cristalinum which have six. The length of gill filaments and form of the cocoon further distinguish S. paynei, S. rubrithorax, and S. virgatum s.l. from S. lobatoi. In S. rubrithorax mean pupal gill length is $3.2 \mathrm{~mm}$ (range 2.5-5.4 mm) (Shelley et al. 1997) and in S. virgatum $2.6 \mathrm{~mm}$ (range 1.8-3.1 mm) (Shelley et al. 2002) compared to $S$. lobatoi where the mean is $1.3 \mathrm{~mm}$ (range 0.9-1.8 mm). In the former three species all filaments are rounded or weakly pointed distally and forwardly directed and the cocoon has prominent fenestrations (Shelley et al. 1997, 2002), whereas in S. lobatoi gill filaments are strongly pointed distally and upwardly directed, and the cocoon does not have fenestrations (Figs 18-19).

DISTRIBUTION. S. lobatoi has a limited distribution around its type locality Tangará da Serra. It has also been found in Cachoeira da Lageado, Cachoeira de Pequizeiro (Mato Grosso), and in the Planalto highland area of Goiás (Salto de Itiquira and Minaçu) (material examined). It occurs with S. auripellitum Enderlein, S. clarki Fairchild, $S$. guianense Wise (complex), S. rubrithorax Lutz, and $S$. spinibranchium Lutz (APA Luna Dias, unpublished data).

BIOLOGY AND MEDICAL IMPORTANCE. The alimentary habits of $S$. lobatoi are not well known, although few specimens were collected biting man in Cachoeira do Pequizeiro. Adults were reared from immature stages that were collected in small to medium $(50 \mathrm{~cm}$ to $10 \mathrm{~m}$ wide), clear, fast flowing rivers, with pupae attached to rocks and dead leaves in parts of the river where the current is faster.

ETYMOLOGY. The species name is dedicated to Professor Wladimir Lobato Paraense, who has been responsible for stimulating and supporting contemporary research on Simuliidae in Brazil.

\section{MATERIALEXAMINED}

Simulium lobatoi, new species

\section{BRAZIL}

\section{Goiás}

PINNED

Salto de Itiquira, (site 1138); 7.viii.1996, (APA Luna Dias \& PR Garritano) - 2 females 1 male (reared) [PARATYPES] (IOC, BMNH). Formosa, $34 \mathrm{~km}$ from Formosa before Ponte Salto do Itiquira, (site 1094); 8.v.1996, (APA Luna Dias \& PR Garritano) - 2 males (reared) [PARATYPES] (BMNH, IOC). Cachoeira de Lageado, $4 \mathrm{~km}$ from entrance to road to Serra da Mesa, (site 1286); 27.ix.1997, (APA Luna Dias \& PR Garritano) - 20 females 7 males (reared) [PARATYPES] (BMNH, IOC).

\section{SLIDES}

Minaçu area, Rio Tocantins; 28.ix.1995, (M Carmargo) - 1 male (reared) [PARATYPE] (BMNH) [previously identified as Simulium nigrimanum Macquart]. Cachoeira de Lageado, $4 \mathrm{~km}$ from entrance to road to Serra da Mesa, (site 1286); 27.ix.1997, (APA Luna Dias \& PR Garritano) - 2 females 3 males (reared) [PARATYPES] (BMNH).

\section{Mato Grosso}

PINNED

Tangará da Serra, Estância Primavera, Cachoeira I, (site 1053); 26.v.1995, (APA Luna Dias, PR Garritano, MM Elázaro \& M Leila) - 1 female (reared) [HOLOTYPE] (IOC). Tangará da Serra, Estância Primavera, (site 1054); 26.v.1995, (APA Luna Dias, PR Garritano, MM Elázaro \& M Leila) - 2 females (reared) [PARATYPES] (BMNH, IOC). Tangará da Serra, Estância Primavera, Cachoeira I; 24.v.1995, (APA Luna Dias, PR Garritano) - 1 female 1 male (reared) [PARATYPES] (BMNH). Cachoeira de Pequizeiro, at 75 $\mathrm{km}$ from São Jorge and $41 \mathrm{~km}$ from Alto Paraíso, (site 1141); 8.viii.1996, (APA Luna Dias \& PR Garritano) - 4 females (man-biting), 1 female (reared, no. 1141-1, with genitalia on slide) [PARATYPES] (BMNH, IOC).

\section{SLIDES}

Tangará da Serra, Estância Primavera, (site 1054); 26.v.1995, (APALuna Dias, PR Garritano, MM Elázaro \& M Leila) - 1 female, 1 male (reared) [PARATYPES] (BMNH). Cachoeira de Pequizeiro, at $75 \mathrm{~km}$ from São Jorge and $41 \mathrm{~km}$ from Alto Paraíso, (site 1141); 8.viii.1996, (APA Luna Dias \& PR Garritano) - 2 females (man-biting), 1 female (reared, no. 1141-1, only genitalia, adult pinned) [PARATYPE] (BMNH).

\section{Simulium brachycladum Lutz \& Pinto, 1932}

\section{BRAZIL}

\section{Bahia}

PINNED

BR 101, Salvador to Ilheus, R Sururu; 24.viii.1993, (AJ Shelley, M Maia-Herzog \& APA Luna Dias) - 2 females 2 males (reared) (BMNH, BM-1994-254).

\section{Pernambuco}

PINNED

Morena/Bonanza, (site 528); 3.i.1981, (R Malaguti) - 1 female 1 male (reared) (BMNH). Nova Referina, $20 \mathrm{~km}$ before Catendo on Rd from Caruaru, R Una; 19.vii.1994, (AJ Shelley, M Maia-Herzog \& APA Luna Dias) - 1 female (swarming), 1 male (reared) (BMNH).

\section{Rio de Janeiro PINNED}

Itaguaí, (site 661-1); 10.v.1983, (APA Luna Dias) - 2 females 2 males (reared) (BMNH). Itaguaí; 2.v.1995, (R Calvão) - 7 females (reared, only one female with pupa) 2 males (reared, without pupae) (BMNH).

\section{São Paulo \\ PINNED}

North of Serra da Bocaina, (locality 14); 15-18.v.1979, (RW Crosskey \& AJ Shelley) - 11 females (reared, 7 without pupae) 4 males (reared, 3 without pupae) (BMNH, BM1979-258). North of Serra da Bocaina, km 18, BR 139; 15- 
18.v.1979, (RW Crosskey \& AJ Shelley) - 1 male (reared), (BMNH, BM-1979-258).

\section{SLIDES}

North of Serra da Bocaina, km 18, BR 139, (no. 451); 1518.v.1979, (RW Crosskey \& AJ Shelley) - 1 female 2 males (reared), 3 pupae (BMNH, BM-1979-258).

\section{SPIRIT}

North of Serra da Bocaina, (locality 14); 15-18.v.1979, (RW Crosskey \& AJ Shelley) - several pupae (BMNH, BM1979-258).

Simulium cristalinum Coscarón \& Py-Daniel, 1989

BRAZIL

PINNED

Roraima

Near Uiramutão, R Cotingo, (site 1308); 1.xi.1997, (AJ Shelley \& APA Luna Dias) - 1 female 1 male (reared) (BMNH).

\section{Simulium rubrithorax Lutz, 1909}

The material listed under S. rubrithorax in Shelley et al. (1997) was examined for this paper.

\section{Simulium scutistriatum Lutz, 1909}

\section{BRAZIL}

\section{Rio de Janeiro}

PINNED

Represa dos Ciganos, (no. 9-52-cano); 10.vii.1984, (M Maia-Herzog \& AR Figueiredo) - 1 male (reared) (BMNH).

\section{SLIDES}

Rep. dos Ciganos, (no.7-14/cano); 18.vi.1984, (M Malaguti $\&$ MG de Castro) - 1 female (reared) (BMNH).

\section{Simulium virgatum Coquillett (species complex)}

The material listed under $S$. virgatum s.l. in Shelley et al. (2002) was examined for this paper.

\section{REFERENCES}

Charalambous M, Shelley AJ, Maia-Herzog M, Luna Dias APA 1996. Four new cytotypes of the onchocerciasis vector blackfly Simulium guianense in Brazil. Med Vet Entomol 10: 111-120.

Coscáron S 1987. El género Simulium Latreille en la Región Neotropical: Análisis de los Grupos Supraspecíficos, Especies que los Integran y Distribución Geográfica (Simuliidae, Diptera), Museu Paraense Emílio Goeldi, Belém, $112 \mathrm{pp}$.

Coscarón S, Cerqueira RL de, Schumaker TTS, Salvia Filho V 1992. Nuevos datos sobre distribución de simulidos de Brasil y descripción de Simulium (Coscaroniellum) cerradense sp. n. (Diptera, Simuliidae). Rev Brasil Entomol 11: 111119.

Crosskey RW, Howard TM 1997. A New Taxonomic and Geographical Inventory of World Blackflies (Diptera: Simuliidae), The Natural History Museum, London, 144 pp.

Hamada N 2000. Simulium (Psaroniocompsa) tergospinosum new species (Diptera: Simillidae) in siolii group from southern part of the state of Amazonas, Brazil. Mem Inst Oswaldo Cruz 95: 819-828.

Hamada N, Adler PH 1998a. Taxonomy of the Simulium perflavum species-group (Diptera:Simuliidae) with description of a new species from Brazil. Insecta Mundi 12: 207226.

Hamada N, Adler PH 1998b. A new species of Simulium (Diptera: Simuliidae) from open areas in Central Amazonia, Brazil. Mem Inst Oswaldo Cruz 93: 317-325.

Hamada N, Adler PH 1999. Cytotaxonomy of four species in the Simulium perflavum species group (Diptera; Simuliidae) from Brazilian Amazonia. Syst Entomol 24: 273-288.

Hamada N, Ale-Rocha R, Luz SLB 2003. Description of Simulium damascenoi (Diptera, Simuliidae) male and the blackfly species from the state of Amapá, Brazil. Mem Inst Oswaldo Cruz 98: 353-360.

Maia-Herzog M, Shelley AJ, Bradley JE, Luna Dias APA, Calvão RHS, Lowry C, Camargo M, Rubio JM, Post RJ, Coelho GE 1999. Discovery of a new focus of human onchocerciasis in Central Brazil. Trans R Soc Trop Med Hyg 93: 235-239.

Maia-Herzog M, Shelley AJ, Luna Dias APA, Malaguti R 1984. Comparação entre Simulium brachycladum e Simulium rubrithorax, suas posições no subgênero Hemicnetha e notas sobre uma espécie próxima, S. scutistriatum (Diptera: Simuliidae). Mem Inst Oswaldo Cruz 79: 341-356.

Py-Daniel V 1997. Oncocercose, uma endemia focal no hemisfério norte da Amazônia. In RI Barbosa, EJG Ferreira, EG Castellón (eds) Homem, Ambiente e Ecologia no Estado de Roraima, Inpa, Manaus, p. 111-155.

Shelley AJ 1988. Vector aspects of the epidemiology of oncherciasis in Latin America. Ann Rev Entomol 33: 337 366.

Shelley AJ 2002. Human onchocerciasis in Brazil: an overview. Cad Saúde Púb 18: 1167-1177.

Shelley AJ, Arzube M, Couch CA 1989. The Simuliidae (Diptera) of the Santiago onchocerciasis focus in Ecuador. Bull Brit Mus Nat Hist (Entomol) 58: 79-130.

Shelley AJ, Hernández, LM, Penn M 2002. A biosystematic revision of the blackflies (Diptera: Simuliidae) of Belize, Central America. Bull Nat Hist Mus (Entomol) 71: 135-271.

Shelley AJ, Lowry CA, Maia-Herzog M, Luna Dias APA, Moraes MAP 1997. Biosystematic studies on the Simuliidae (Diptera) of the Amazonia onchocerciasis focus of Brazil. Bull Nat Hist Mus (Entomol) 66: 1-121.

Shelley AJ, Maia-Herzog M, Lowry CA, Luna Dias APA, Garritano PR, Shelley A, Camargo M, Carter HG 2000. The Simuliidae (Diptera) of the secondary onchocerciasis focus at Minaçu in Central Brazil. Bull Nat Hist Mus (Entomol) 69: 171-221.

Shelley AJ, Maia-Herzog M, Luna Dias APA, Camargo M, Costa EG, Garritano, Lowry CA 2001a. Biting behaviour and potential status of anthropophilic blackflies in a new focus of human onchocerciasis at Minaçu, Central Brazil. Med Vent Entomol 15: 28-39.

Shelley AJ, Maia-Herzog M, Luna Dias APA, Lowry CA, Penn M, Garritano P, Camargo M 2001b. Simulium cuasiexiguum, a new blackfly species (Diptera:Simuliidae) from the Minaçu onchocerciasis focus in the state of Goiás, Central Brazil. Mem Inst Oswaldo Cruz 96: 483-296.

Strieder NM, Coscarón S 2000. El estado de Simulium (Psaroniocompsa) (Diptera, Simuliidae) en la región sur de Brasil y Argentina, con descripción de Simulium minuanum sp. n. Entomol Vect 7: 101-117.

Strieder MN, Py-Daniel V 2000. Revisão de Inaequalium (Diptera, Simuliidae) com redescrição das formas imaturas e descrição de uma nova espécie. Entomol Vect 7: 1-91. 